\title{
Blood Calcium Levels in Immature Rats: Influence of Extracellular Calcium Concentration on Myocardial Calcium Handling
}

\author{
Rosana A. BASSANI'), Rovilson GILIOLI' ${ }^{2}$, Elizângela S. OLIVEIRA' ${ }^{1)}$, and Nelci F. HOEHR ${ }^{3)}$ \\ 1) Center for Biomedical Engineering, University of Campinas, 181 Alexander Fleming St, 13083-881 Campinas, \\ SP, Brazil \\ 2) Multidisciplinary Center for Biological Investigation on Laboratory Animals Science, University of Campinas, \\ 05 de Junho St., 13083-877 Campinas, SP, Brazil \\ ${ }^{3)}$ Department of Clinical Pathology, School of Medical Sciences. University of Campinas, 181 Alexander Fleming \\ St, 13083-881 Campinas, SP, Brazil
}

\begin{abstract}
Calcium ions play an important role in several cell functions, from fertilization to cell death. The cytosolic $\mathrm{Ca}^{2+}$ concentration is much lower than the extracellular concentration $\left(\left[\mathrm{Ca}^{2+}\right]_{0}\right)$. The latter may markedly affect $\mathrm{Ca}^{2+}$ fluxes across the cell membrane and thus the cellular $\mathrm{Ca}^{2+}$ load. Thus, when working with preparations in vitro, it is important to keep $\left[\mathrm{Ca}^{2+}\right]_{0}$ close to the in vivo value. In this study, we determined the calcemia in immature rats, for which values are currently unavailable, and investigated how supraphysiological $\left[\mathrm{Ca}^{2+}\right]_{0}$ affects myocardial $\mathrm{Ca}^{2+}$ handling. Blood ionized $\left[\mathrm{Ca}^{2+}\right]$ was similar in neonatal $(2-5$ days old $)$ and adults Wistar rats $(1.28 \pm 0.03$ and $1.31 \pm 0.03$ $\mathrm{mmol} / / ; \mathrm{n}=6$ and 5 , respectively, $P>0.37)$, and lower than the $\left[\mathrm{Ca}^{2+}\right]_{0}$ range often used in experiments with neonatal myocardial preparations. Cytosolic $\mathrm{Ca}^{2+}$ transients, measured with indo- 1 in neonatal ventricular myocytes, were enhanced by an increase in $\left[\mathrm{Ca}^{2+}\right]_{0}$ from 1.2 to $2 \mathrm{mM}$, which also increased the $\mathrm{Ca}^{2+}$ content in the sarcoplasmic reticulum (SR), and changed the pattern of competition between the main transporters that remove $\mathrm{Ca}^{2+}$ from the cytosol ( $\mathrm{SR} \mathrm{Ca}^{2+}$-ATPase and $\mathrm{Na}^{+} / \mathrm{Ca}^{2+}$ exchanger). These observations stress the importance of using physiological $\left[\mathrm{Ca}^{2+}\right]_{0}$ values for reliability of results. It is expected that the present calcemia data, reported for the first time in immature rats, may contribute to the refinement of in vitro experiments with neonatal rat preparations.
\end{abstract}

Key words : calcemia, excitation-contraction coupling, myocardium, neonatal rat

\section{Introduction}

Calcium ions are cytotoxic when present at a high concentration in the intracellular medium. It is believed that early in evolution, cells have developed mechanisms to maintain the intracellular free $\mathrm{Ca}^{2+}$ concentration $\left(\left[\mathrm{Ca}^{2+}\right]_{\mathrm{i}}\right)$ at very low levels $(100-200 \mathrm{nM})$, which are approximately 4 orders of magnitude lower than the extracellular concentration $\left(\left[\mathrm{Ca}^{2+}\right]_{0}\right)$ in vertebrates [11].
Consequently, a high transmembrane electrochemical gradient is established, which favors $\mathrm{Ca}^{2+}$ influx through $\mathrm{Ca}^{2+}$ channels and transporters. From fertilization to apoptosis, $\mathrm{Ca}^{2+}$ plays a key role in the signaling of several processes: an increase in $\left[\mathrm{Ca}^{2+}\right]_{\mathrm{i}}$ due to transmembrane influx and/or release from intracellular stores is involved in regulation of cell proliferation, secretion, transcription, energetic metabolism, electrical activity, and contraction development [9].

(Received 13 September 2011 / Accepted 18 December 2011)

Address corresponding: R. A. Bassani, Center for Biomedical Engineering, UNICAMP, Alexander Fleming St. 181, 13083-881 Campinas, SP, Brazil

C2012 Japanese Association for Laboratory Animal Science 
Transmembrane $\mathrm{Ca}^{2+}$ fluxes are highly dependent on the electrochemical gradient of the ion across the membrane and consequently on $\left[\mathrm{Ca}^{2+}\right]_{0}$. On the other hand, the $\mathrm{Ca}^{2+}$ content of intracellular compartments is expected to be affected by the availability of the ion, which depends on the balance of transmembrane inward and outward fluxes. Thus, to better reproduce the in vivo conditions, the $\left[\mathrm{Ca}^{2+}\right]_{0}$ used in in vitro studies should be close to that of the extracellular compartment.

Comparison of the blood/serum $\left[\mathrm{Ca}^{2+}\right]$ in immature and adult mammalians has shown variable results, i.e., greater, lower and similar values to those in adults have been observed in neonates, depending on the species [8, $17,18,21,30]$. Nevertheless, information on the values of blood/serum ionized $\left[\mathrm{Ca}^{2+}\right]$ in immature rats is not currently available in the literature, although preparations from neonatal rodents, especially cardiomyocytes, are widely used for several kinds of studies (e.g., biochemistry, biophysics, genetics, physiology, pharmacology, bioengineering). As a result, variable $\left[\mathrm{Ca}^{2+}\right]_{\mathrm{o}}$ values have been used in vitro, which, if unrealistic, may lead to functional alterations and compromise the reliability of the results and conclusions.

The aims of the present study were: a) to determine the ionized $\left[\mathrm{Ca}^{2+}\right]$ in the blood of neonatal rats; and b) to analyze the impact of exposing immature cardiomyocytes to a supraphysiological $\left[\mathrm{Ca}^{2+}\right]_{0}$ value, often used in experiments with this preparation, on electricallyevoked $\mathrm{Ca}^{2+}$ transients and on the sarcoplasmic reticulum (SR) $\mathrm{Ca}^{2+}$ content.

\section{Materials and Methods}

Determination of the blood concentration of ionized $\mathrm{Ca}^{2+}$ Specific pathogen-free Wistar Hannover rats (UnibHan:Wistar strain; colony originally established at CEMIB/UNICAMP with rats acquired from the Zentralinstitut für Versuchstierzucht, Hannover, Germany, in 1987) bred under protection barrier system conditions at CEMIB/UNICAMP (an ICLAS monitoring/reference center) were used; these included adult males (3-4 months old, $n=5$ ) not submitted to previous fasting, and neonates of both sexes ( $2-5$ days old, $n=11$ ) from different litters. The latter remained with the dams until the experiment to minimize fast-induced changes in blood $\mathrm{pH}$ and other parameters. Adult animals were maintained at $22 \pm 2^{\circ} \mathrm{C}$, under a $12: 12 \mathrm{~h}$ dark-light cycle (lights on at $7 \mathrm{AM}$ ), with free access to water and pelleted chow
(Nuvilab CR-1, Nuvital, Brazil).

All blood samples were collected at 2-4 PM to minimize interference of diurnal variations [20]. Adult rats were anesthetized with ketamine plus xylazine (50 and $10 \mathrm{mg} / \mathrm{kg}$, respectively, i.p.), whereas the anesthesia procedure chosen for neonates was halothane inhalation, as injectable anesthetics have been shown to cause greater mortality and to be less effective for short-term surgical anesthesia in neonatal rodents than inhalant anesthesia [12]. Blood was collected by cardiac puncture into dry, lithium heparin-containing syringes (PICO50, Radiometer, Copenhagen, Denmark), mixed gently, and briefly stored at $4^{\circ} \mathrm{C}$. In most cases, blood samples from 2 neonates were pooled. After collection, animals were sacrificed by carbon dioxide inhalation. Ionized $\left[\mathrm{Ca}^{2+}\right]$ in the whole blood was measured with a Radiometer ABL800 Flex analyzer within less than $1 \mathrm{~h}$ after collection. The protocol for care and use of the animals was approved by the institutional Committee of Ethics in Animal Research (CEUA/IB/UNICAMP, protocol number 2228-1).

Experiments with ventricular myocytes isolated from immature rats

Ventricular myocytes were isolated from 5-day-old Wistar rats $(\mathrm{n}=4)$ by coronary perfusion with collagenase $1(0.5 \mathrm{mg} / \mathrm{ml}$, Worthington Biochem, Lakewood, NJ, USA), according to Bassani and Bassani [4]. Cells were used within $6 \mathrm{~h}$ after isolation.

For $\left[\mathrm{Ca}^{2+}\right]_{\mathrm{i}}$ measurement, myocytes were incubated with indo-1 AM ( $5 \mu \mathrm{M}$; Molecular Probes, Eugene, OR, USA) for $10 \mathrm{~min}$, and then perfused for $30 \mathrm{~min}$ for deesterification of the dye. Cells were electrically stimulated at $1 \mathrm{~Hz}$ under perfusion with modified Tyrode's solution (TS; composition in mM: $140 \mathrm{NaCl}, 6 \mathrm{KCl}$, $\mathrm{MgCl}_{2}$ 1, HEPES 5, glucose 11, pH 7.4) containing 1.2 $\mathrm{mM} \mathrm{CaCl}_{2}$. Two types of caffeine-evoked $\mathrm{Ca}^{2+}$ transients were obtained in the absence of electrical stimulation [2, 5]: a) the first type was evoked by switching perfusion to TS containing $10 \mathrm{mM}$ caffeine (Caf-TS) after a $5 \mathrm{~s}$ rest; and b) in the second type, cells were perfused with $\mathrm{Na}^{+}-, \mathrm{Ca}^{2+}$-free TS solution (equimolar replacement of $\mathrm{NaCl}$ and $\mathrm{CaCl}_{2}$ with $\mathrm{LiCl}$ and EGTA, respectively) for $20 \mathrm{~s}$, followed by switching to the same solution containing $10 \mathrm{mM}$ caffeine (Caf-00). Cells were electrically stimulated for $2 \mathrm{~min}$ prior to caffeine application. Afterward, the same protocol was repeated during perfusion with TS containing $2 \mathrm{mM} \mathrm{CaCl}_{2}$. The caffeine solution 
used to evoke Caf-TS also contained $2 \mathrm{mM} \mathrm{CaCl}_{2}$.

Indo-1 was excited at $360 \mathrm{~nm}$. After fluorescence background subtraction, the ratio of emission at 410 and $485 \mathrm{~nm}$ was converted to $\left[\mathrm{Ca}^{2+}\right]_{\mathrm{i}}$ according to Bassani and Bassani [4].

The rate of $\left[\mathrm{Ca}^{2+}\right]_{\mathrm{i}}$ decline $(k)$ during electrically evoked twitches, Caf-TS and Caf-00 was determined by exponential fitting of the decaying phase of the $\mathrm{Ca}^{2+}$ transient. The $\mathrm{SR} \mathrm{Ca}^{2+}$ content was estimated as the difference in total $\left[\mathrm{Ca}^{2+}\right]\left(\left[\mathrm{Ca}^{2+}\right]_{\mathrm{T}}\right)$, i.e., the sum of free and bound $\left.\left[\mathrm{Ca}^{2+}\right]\right)$ at the peak and immediately before the Caf-00 transient [10], and expressed as $\mu \mathrm{mol} \mathrm{Ca}^{2+}$ per liter of non-mitochondrial cell water. For $\left[\mathrm{Ca}^{2+}\right]_{\mathrm{T}}$ estimation, $\mathrm{Ca}^{2+}$ binding to both indo- 1 and endogenous passive $\mathrm{Ca}^{2+}$ buffers was taken into account, assuming [indo-1] as $20 \mu \mathrm{M}$, and considering the endogenous $\mathrm{Ca}^{2+}$ buffering parameters determined in the myocardium of neonatal rats [7].

From the $\left[\mathrm{Ca}^{2+}\right]_{\mathrm{i}}$ data, as well as from the estimated $\left[\mathrm{Ca}^{2+}\right]_{\mathrm{T}}$ and $k$ values of the different types of transients, the empirical maximum velocity of $\mathrm{Ca}^{2+} \operatorname{transport}\left(V_{\max }\right)$ was determined for the different transporters, i.e., SR $\mathrm{Ca}^{2+}$-ATPase (SERCA), $\mathrm{Na}^{+} / \mathrm{Ca}^{2+}$ exchanger (NCX), and the combination of the slow systems (i.e., sarcolemmal $\mathrm{Ca}^{2+}$-ATPase and mitochondrial $\mathrm{Ca}^{2+}$ uniporter), as described by Bassani et al. [2], using the equation

$$
d\left[\mathrm{Ca}^{2+}\right]_{\mathrm{T}} / d\left[\mathrm{Ca}^{2+}\right]_{\mathrm{i}}=\mathrm{V}_{\max } /\left\{\left(1+\mathrm{K}_{\mathrm{m}}\right)^{\mathrm{n}}\right\},
$$

where $K_{m}$ and $n$ represent the Michaelis-Menten constant and the Hill coefficient, respectively.

Data are presented as means accompanied by the respective standard error and/or $95 \%$ confidence interval (CI95\%). Blood ionized $\left[\mathrm{Ca}^{2+}\right]$ values in adults and neonates were compared with the Student's $t$-test for unpaired samples. The Student's $t$-test for paired samples was used for comparison of variables of the in vitro experiments. $P<0.05$ was considered to indicate significance.

\section{Results}

As shown in Fig. 1, blood ionized $\left[\mathrm{Ca}^{2+}\right]$ in neonatal rats was $1.28 \pm 0.03 \mathrm{mmol} / 1$ (CI95\%: $1.21-1.35 \mathrm{mmol} / \mathrm{l}$; $\mathrm{n}=6)$, which was not statistically different $(P>0.35)$ from that in adult rats $(1.31 \pm 0.03 \mathrm{mmol} / \mathrm{l} ; \mathrm{CI} 95 \%: 1.24-1.39$ $\mathrm{mmol} / \mathrm{l} ; \mathrm{n}=5$ ).

The amplitude of $\mathrm{Ca}^{2+}$ transients recorded from neonatal rat ventricular myocytes paced at $1 \mathrm{~Hz}$ was enhanced by $70 \%$ after $\left[\mathrm{Ca}^{2+}\right]_{0}$ was raised from 1.2 to 2

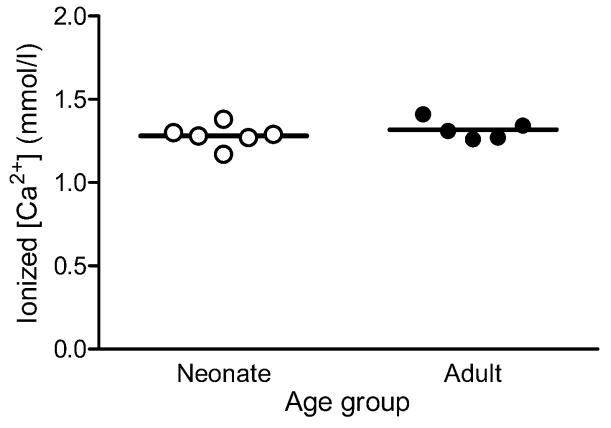

Fig. 1. Ionized $\mathrm{Ca}^{2+}$ concentration in the blood of neonatal (2-5 days of age) and adult (3-4 month old) Wistar rats. The horizontal lines represent the mean values in each group.
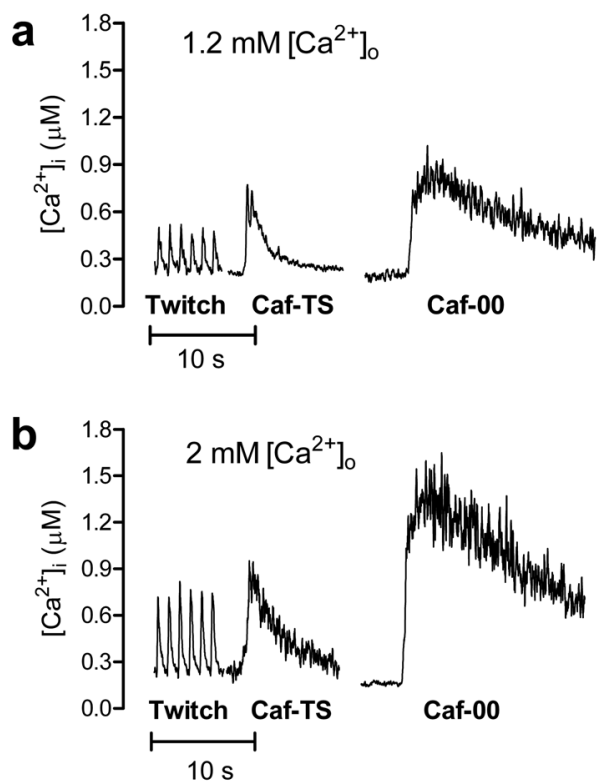

Fig. 2. $\mathrm{Ca}^{2+}$ transients evoked by electric stimulation at $1 \mathrm{~Hz}$ (twitch) and by application of $10 \mathrm{mM}$ caffeine dissolved in Tyrode's solution with or without $\mathrm{Na}^{+}$and $\mathrm{Ca}^{2+}$ (Caf-TS and Caf-00, respectively), and recorded from a 5-day-old rat ventricular myocyte in the presence of 1.2 and $2 \mathrm{mM}$ extracellular $\left[\mathrm{Ca}^{2+}\right]\left(\left[\mathrm{Ca}^{2+}\right]_{0}\right)$.

$\mathrm{mM}(P<0.001$; Fig. 2$)$, and the $k$ value of $\left[\mathrm{Ca}^{2+}\right]_{\mathrm{i}}$ decline was significantly increased $(P<0.05)$. A small but significant increase in diastolic $\left[\mathrm{Ca}^{2+}\right]_{\mathrm{i}}$ was also observed $(P<0.001)$. In addition, raising $\left[\mathrm{Ca}^{2+}\right]_{0}$ to $2 \mathrm{mM}$ resulted in a $23 \%$ increase in the $\mathrm{SR} \mathrm{Ca}^{2+}$ content $(P<0.001)$ (Table 1).

The $\left[\mathrm{Ca}^{2+}\right]_{\mathrm{i}}$ elevation induced by caffeine is attributed to release of the $\mathrm{SR} \mathrm{Ca}^{2+}$ content due to the opening of 
Table 1. Amplitude and rate constants of decline $(k)$ of $\mathrm{Ca}^{2+}$ transients evoked by electric stimulation (twitch) and by application of $10 \mathrm{mM}$ caffeine dissolved in Tyrode's solution with or without $\mathrm{Na}^{+}$and $\mathrm{Ca}^{2+}$ (Caf-TS and Caf00 , respectively), as well as the sarcoplasmic reticulum (SR) $\mathrm{Ca}^{2+}$ content, in isolated ventricular myocytes from 5-day-old rats exposed to different extracellular $\mathrm{Ca}^{2+}$ concentrations $\left(\left[\mathrm{Ca}^{2+}\right]_{\mathrm{o}}\right)$

\begin{tabular}{lcc}
\hline & $1.2 \mathrm{mM}\left[\mathrm{Ca}^{2+}\right]_{\mathrm{o}}$ & $2.0 \mathrm{mM}\left[\mathrm{Ca}^{2+}\right]_{\mathrm{o}}$ \\
\hline Twitch & & \\
Diastolic $\left[\mathrm{Ca}^{2+}\right]_{\mathrm{i}}(\mu \mathrm{M})$ & $0.226 \pm 0.006$ & $0.246 \pm 0.007^{*}$ \\
Amplitude $(\mu \mathrm{M})$ & $0.313 \pm 0.022$ & $0.528 \pm 0.036^{*}$ \\
$k\left(\mathrm{~s}^{-1}\right)$ & $4.440 \pm 0.200$ & $5.174 \pm 0.379^{*}$ \\
$\mathrm{Caf}-\mathrm{TS}$ & & \\
Amplitude $(\mu \mathrm{M})$ & $0.724 \pm 0.040$ & $0.982 \pm 0.079^{*}$ \\
$k\left(\mathrm{~s}^{-1}\right)$ & $0.767 \pm 0.061$ & $0.476 \pm 0.032^{*}$ \\
$\mathrm{Caf}-00$ & & \\
Amplitude $(\mu \mathrm{M})$ & $0.878 \pm 0.046$ & $1.569 \pm 0.160^{*}$ \\
$k\left(\mathrm{~s}^{-1}\right)$ & $0.104 \pm 0.019$ & $0.085 \pm 0.016$ \\
$\mathrm{SR} \mathrm{Ca}$ & & \\
$(\mu \mathrm{mol} / 1$ cell water $)$ & $76.5 \pm 2.4$ & $94.5 \pm 2.8^{*}$ \\
\hline
\end{tabular}

Number of studied cells $=18$. ${ }^{*} P<0.05$ vs. $1.2\left[\mathrm{Ca}^{2+}\right]_{\mathrm{o}}$ (Student's $t$-test for paired samples).

the $\mathrm{SR} \mathrm{Ca}^{2+}$ release channels by the alkaloid [24]. The amplitude of both types of caffeine-induced transients was augmented at 2 vs. $1.2 \mathrm{mM}\left[\mathrm{Ca}^{2+}\right]_{\mathrm{o}}(P<0.01$; Fig. 2). In contrast with the acceleration of $\left[\mathrm{Ca}^{2+}\right]_{\mathrm{i}}$ decline during twitches, the $k$ value for Caf-TS was significantly decreased at the higher $\left[\mathrm{Ca}^{2+}\right]_{0}(P<0.01$; Table 1), although the amplitude of the transient was greater. The $\left[\mathrm{Ca}^{2+}\right]_{\mathrm{i}}$ decline during Caf-00 was slowed in some cells, but the difference in $k$ values did not attain statistical significance $(P>0.08)$.

Figure 3 shows the empirical $V_{\max }$ values estimated for SERCA, NCX and the slow $\left[\mathrm{Ca}^{2+}\right]_{0}$ transporters. Whereas $\left[\mathrm{Ca}^{2+}\right]_{0}$ did not exert a significant influence on the $V_{\max }$ of the latter $(P>0.05)$, increasing $\left[\mathrm{Ca}^{2+}\right]_{0}$ from 1.2 to $2 \mathrm{mM}$ reduced NCX $V_{\max }$ by $40 \%(P<0.001)$, but enhanced SERCA $V_{\max }(P<0.01$; Student's $t$-test for paired samples).

\section{Discussion}

To our knowledge, this is the first report of blood ionized $\left[\mathrm{Ca}^{2+}\right]$ values in rats under 1 week of age. The neonatal values determined in this study were comparable to those measured not only in adult rats from different strains $(1.2-1.4 \mathrm{mmol} / 1$ [16, 26, 28]; present results), but also in healthy, full-term human newborns and in adult humans (reference interval: $1.1-1.4 \mathrm{mmol} / 1[1,18,21]$ ).

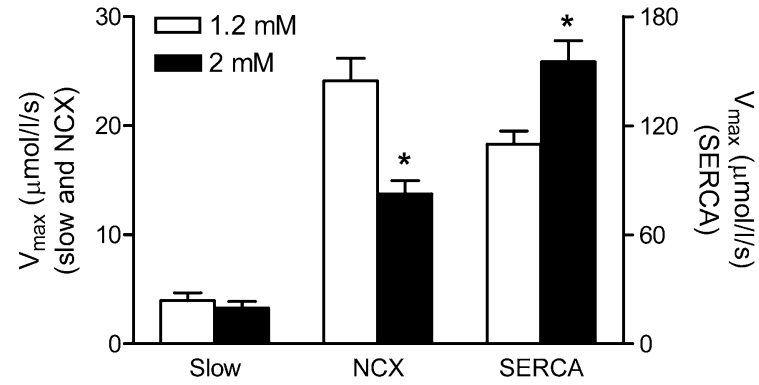

Fig. 3. Empirical values of the maximum velocity of $\mathrm{Ca}^{2+}$ transport $\left(\mathrm{V}_{\max }\right)$ of the sarcoplasmic reticulum $\mathrm{Ca}^{2+}$ ATPase (SERCA; right ordinate axis), as well as of $\mathrm{Na}^{+} / \mathrm{Ca}^{2+}$ exchanger (NCX) in the $\mathrm{Ca}^{2+}$ extrusion mode and the slow $\mathrm{Ca}^{2+}$ transporters (slow) (right ordinate axis), determined in neonatal rat ventricular myocytes exposed to 1.2 and $2 \mathrm{mM}$ extracellular $\left[\mathrm{Ca}^{2+}\right]$. Data are expressed as the mean and SEM ( $\mathrm{n}=18) .{ }^{*} P<0.01$ vs $1.2 \mathrm{mM}\left[\mathrm{Ca}^{2+}\right]$ (Student's $t$-test for paired samples).

Specifically regarding the immature myocardium, important developmental differences have been described in the contribution of $\mathrm{Ca}^{2+}$ fluxes across the sarcolemma and the SR membrane. Whereas in the adult rat ventricle it is estimated that approximately $90 \%$ of the $\mathrm{Ca}^{2+}$ cycling takes place between the SR and the cytosol, in neonates, $\mathrm{SR} \mathrm{Ca}^{2+}$ release contributes less $\mathrm{Ca}^{2+}$ to contraction, which relies more on the transsarcolemmal $\mathrm{Ca}^{2+}$ flux than in adults $[4,13,32]$. In experiments with myocardial preparations from developing rats (as well as humans), it is common to use $\left[\mathrm{Ca}^{2+}\right]_{\mathrm{o}}$ values higher $(1.8-2.0 \mathrm{mmol} / \mathrm{l})$ than the blood ionized $\left[\mathrm{Ca}^{2+}\right]$ reported here. High $\left[\mathrm{Ca}^{2+}\right]_{\mathrm{o}}$ is expected to favor systolic $\mathrm{Ca}^{2+}$ influx, while lessening $\mathrm{Ca}^{2+}$ efflux, by increasing the driving force for $\mathrm{Ca}^{2+}$ flux through channels, decreasing the driving force for $\mathrm{Ca}^{2+}$ efflux via the NCX, and enhancing the energy barrier imposed on the sarcolemmal $\mathrm{Ca}^{2+}$ ATPase. These changes would result in a greater cell $\mathrm{Ca}^{2+}$ load, which might modify the contribution of the intracellular and extracellular $\mathrm{Ca}^{2+}$ sources for contraction activation.

The present results of $\left[\mathrm{Ca}^{2+}\right]_{\mathrm{i}}$ measurement in neonatal myocytes confirm such predictions. In the mammalian myocardium, $\mathrm{Ca}^{2+}$ release from the SR, triggered by $\mathrm{Ca}^{2+}$ influx during the action potential, is considered the most important mechanism of excitation-contraction coupling. In the immature heart, however, the colocalization of sarcolemmal and $\mathrm{SR} \mathrm{Ca}^{2+}$ channels (which allows efficient coupling of $\mathrm{Ca}^{2+}$ influx to release) is less prominent, and the $\mathrm{SR} \mathrm{Ca}^{2+}$ release mechanism itself is less 
sensitive to $\mathrm{Ca}^{2+}$ than in adults $[14,25,32]$. Accordingly, we observed that not only the $\left[\mathrm{Ca}^{2+}\right]_{\mathrm{o}}$ transient amplitude, but also the $\mathrm{SR} \mathrm{Ca}^{2+}$ content at a physiological $\left[\mathrm{Ca}^{2+}\right]_{0}$ were considerably lower in neonatal cells than in adult myocytes under similar experimental conditions (see 4 and 10 for comparison). However, both the transient amplitude and SR $\mathrm{Ca}^{2+}$ load were markedly enhanced at $2 \mathrm{mM}\left[\mathrm{Ca}^{2+}\right]_{\text {. }}$.

The increase in the $\mathrm{SR} \mathrm{Ca}^{2+}$ content, as well as the expected greater $\mathrm{Ca}^{2+}$ influx via voltage-dependent $\mathrm{Ca}^{2+}$ channels during excitation (due to the greater transmembrane $\mathrm{Ca}^{2+}$ electrochemical gradient), are probably responsible for the large increase of the twitch $\mathrm{Ca}^{2+}$ transient amplitude at $2 \mathrm{mM}\left[\mathrm{Ca}^{2+}\right]_{0}$, as both factors were shown to enhance the contribution of $\mathrm{SR} \mathrm{Ca}^{2+}$ release to excitation-contraction coupling [3]. It should be stressed that due to the paucity of passive $\mathrm{Ca}^{2+}$ binding sites in immature rat myocardium [7], even relatively small changes in $\mathrm{Ca}^{2+}$ fluxes have a large impact on $\left[\mathrm{Ca}^{2+}\right]_{\mathrm{i}}$ and thus on the several cellular processes affected by it.

Two main factors should contribute to increase the SR $\mathrm{Ca}^{2+}$ content at $2 \mathrm{mM}\left[\mathrm{Ca}^{2+}\right]_{0}$. One of them would be the greater availability of cytosolic $\mathrm{Ca}^{2+}$ to be taken up by SERCA not only because of the greater $\mathrm{Ca}^{2+}$ influx but also due to less $\mathrm{Ca}^{2+}$ extrusion by the NCX, the main sarcolemmal transporter that removes $\mathrm{Ca}^{2+}$ from the cytosol. This may be particularly important in the neonatal myocardium, where NCX expression is higher and the exchanger plays a greater role in cytosolic $\mathrm{Ca}^{2+}$ clearance than in the adult $[4,27,29]$. We estimate that increasing $\left[\mathrm{Ca}^{2+}\right]_{0}$ to $2 \mathrm{mM}$ would cause a $10 \mathrm{mV}$ negative shift of the NCX reversal potential, which should decrease diastolic $\mathrm{Ca}^{2+}$ efflux and possibly favor transport in the $\mathrm{Ca}^{2+}$ influx mode during sarcolemmal depolarization. Accordingly, our present results show that $\left[\mathrm{Ca}^{2+}\right]_{\mathrm{i}}$ decline during Caf-TS was significantly slower after $\left[\mathrm{Ca}^{2+}\right]_{\mathrm{o}}$ was raised. During this type of transient, cytosolic $\mathrm{Ca}^{2+}$ clearance relies mainly on the NCX and, to a lesser extent, on slow transporters [2, 5]. However, $\left[\mathrm{Ca}^{2+}\right]_{\mathrm{i}}$ decay due to the slow transporters alone (Caf- 00 , during which the NCX is thermodynamically inhibited) was not significantly changed. Thus, one may conclude that the slower $\left[\mathrm{Ca}^{2+}\right]_{i}$ decline at Cf-TS is attributable mostly to a decrease in the rate of $\mathrm{Ca}^{2+}$ efflux mediated by the NCX. Accordingly, the empirical $V_{\max }$ value of the slow transporters was not affected by augmenting $\left[\mathrm{Ca}^{2+}\right]_{\mathrm{o}}$ to $2 \mathrm{mM}$, whereas that of the NCX was significantly decreased, which confirms the inhibition of cyto- solic $\mathrm{Ca}^{2+}$ removal by the latter, but not by the slow systems. It is interesting to observe that shifting the NCX reversal potential in the negative direction by either decreasing $\left[\mathrm{Na}^{+}\right]_{0}[15]$ or increasing $\left[\mathrm{Ca}^{2+}\right]_{0}$ (present study) markedly enhances the $\mathrm{SR} \mathrm{Ca}^{2+}$ load in the neonatal ventricle, but not in adult myocardium [15].

The other mechanism that is likely to contribute to greater $\mathrm{SR} \mathrm{Ca}^{2+}$ accumulation at $2 \mathrm{mM}\left[\mathrm{Ca}^{2+}\right]_{\mathrm{o}}$ is stimulation of SERCA activity. This can be inferred from the significant abbreviation of $\left[\mathrm{Ca}^{2+}\right]_{\mathrm{i}}$ decline during electrically stimulated twitches, in spite of the marked prolongation of $\left[\mathrm{Ca}^{2+}\right]_{\mathrm{i}}$ decay during Caf-TS, a transient in which net $\mathrm{SR} \mathrm{Ca}^{2+}$ uptake may be considered negligible. Accordingly, the difference between $k_{t w i t c h}$ and $k_{C a f-T S}$, which may be used as an approximation of the rate constant of $\left[\mathrm{Ca}^{2+}\right]_{\mathrm{i}}$ decay attributable to the $\mathrm{SR} \mathrm{Ca}^{2+}$ uptake [22], was increased from $3.67 \pm 0.20$ to $4.70 \pm 0.38$ $(P<0.02)$ by raising $\left[\mathrm{Ca}^{2+}\right]_{0}$ to $2 \mathrm{mM}$. Enhanced SERCA activity would also explain the relatively small increase in diastolic $\left[\mathrm{Ca}^{2+}\right]_{\mathrm{i}}(<10 \%)$ at $2 \mathrm{mM}\left[\mathrm{Ca}^{2+}\right]_{\mathrm{o}}$, despite the apparent decrease in NCX-mediated $\mathrm{Ca}^{2+}$ efflux. Still, acceleration of $\left[\mathrm{Ca}^{2+}\right]_{\mathrm{i}}$ decline during the twitch might have resulted simply from an increase in the SERCA velocity of transport due to the higher substrate concentration (i.e., $\mathrm{Ca}^{2+}$ ), as the transients were augmented at $2 \mathrm{mM}\left[\mathrm{Ca}^{2+}\right]_{0}$. To assess whether this was the case or else if the enzyme was actually stimulated, we determined the empirical SERCA $V_{\max }$, which is a constant, independent of $\left[\mathrm{Ca}^{2+}\right]_{\mathrm{i}}$. The significant increase in this constant in the presence of $2 \mathrm{mM}\left[\mathrm{Ca}^{2+}\right]_{\mathrm{o}}$ allows the conclusion that acceleration of the twitch $\left[\mathrm{Ca}^{2+}\right]_{\mathrm{i}}$ decline is attributable to SERCA stimulation, rather than to the increase in $\left[\mathrm{Ca}^{2+}\right]_{\mathrm{i}}$ itself.

A possible mechanism underlying SERCA stimulation is enhanced phosphorylation of phospholamban, a negative regulator of SERCA, by the $\mathrm{Ca}^{2+} /$ calmodulin-dependent kinase II (CaMKII) [19]. As the temporal average of $\left[\mathrm{Ca}^{2+}\right]_{i}$ should be increased at $2 \mathrm{mM}\left[\mathrm{Ca}^{2+}\right]_{0}$, greater activity of this enzyme in the autonomous state would be expected [19]. CaMKII was shown to play an important role in the SERCA-dependent $\left[\mathrm{Ca}^{2+}\right]_{\mathrm{i}}$ decline in adult rat cardiomyocytes paced at $1 \mathrm{~Hz}$ and to affect the empirical SERCA $V_{\max }[6,23]$. On the other hand, evidence is available that CaMKII is active and able to phosphorylate phospholamban and other proteins associated with the SR in the mammalian myocardium even before birth [31].

In general, the changes in myocardial $\mathrm{Ca}^{2+}$ transients 
brought about by exposure to an unphysiologically high $\left[\mathrm{Ca}^{2+}\right]_{\mathrm{o}}$ indicate a shift in the pattern of $\mathrm{Ca}^{2+}$ handling and competition between SR (i.e., SERCA) and sarcolemmal (i.e., NCX) transporters toward that observed in the adult cells, in which $\mathrm{Ca}^{2+}$ cycling between the SR and the cytosol is more prominent. This is particularly important when one has in mind the widespread use of cells from neonatal rats (mostly cultured cardiac cells) in several kinds of experiments, from studies on gene regulation to drug tests. It is expected that the present results may contribute to the refinement of such experiments by the use of a more realistic ionic composition of the extracellular medium, which should lead to more reliable results and conclusions. Considering the importance of $\left[\mathrm{Ca}^{2+}\right]_{i}$ for a myriad of cellular processes, alterations in cellular $\mathrm{Ca}^{2+}$ balance in the presence of unrealistic $\left[\mathrm{Ca}^{2+}\right]_{0}$ values may affect results of experiments with other tissue and cell types, in addition to the myocardium.

\section{Acknowledgments}

This study received financial support from FAPESP/ Brazil (Proc. N. 2008/54795-6). Syringes were a kind gift from Netmel Instrumentos Científicos (Rio de Janeiro, RJ, Brazil). The technical support of Ms. Marielza C.F. Lot is acknowledged.

\section{References}

1. Baird, G.S., Rainey, P.M., Wener, M., and Chandler, W. 2009. Reducing routine ionized calcium measurement. Clin. Chem. 55: 533-540. [Medline] [CrossRef]

2. Bassani, J.W.M., Bassani, R.A., and Bers, D.M. 1994. Ralaxation in rabbit and rat cardiac cells: species-dependent differences in cellular mechanisms. J. Physiol. 476: 279293. [Medline]

3. Bassani, J.W.M., Yuan, W., and Bers, D.M. 1995. Fractional SR Ca release is regulated by trigger $\mathrm{Ca}$ and SR Ca content in cardiac myocytes. Am. J. Physiol. 268: C1313-C1319. [Medline]

4. Bassani, R.A. and Bassani, J.W.M. 2002. Contribution of $\mathrm{Ca}^{2+}$ transporters to relaxation in intact ventricular myocytes from developing rats. Am. J. Physiol. Heart Circ. Physiol. 282: H2406-H2413. [Medline]

5. Bassani, R.A., Bassani, J.W.M., and Bers, D.M. 1992. Mitochondrial and sarcolemmal $\mathrm{Ca}^{2+}$ transport reduce $\left[\mathrm{Ca}^{2+}\right]_{\mathrm{i}}$ during caffeine contractures in rabbit cardiac myocytes. $J$. Physiol. 453: 591-608. [Medline]

6. Bassani, R.A., Mattiazzi, A., and Bers, D.M. 1995. CaMKII is responsible for activity-dependent acceleration of relaxation in rat ventricular myocytes. Am. J. Physiol. 268: H703-
H712. [Medline]

7. Bassani, R.A., Shannon, T.R., and Bers, D.M. 1998. Passive $\mathrm{Ca}^{2+}$ binding in ventricular myocardium of neonatal and adult rats. Cell Calcium 23: 433-442. [Medline] [CrossRef]

8. Berlin, D. and Aroch, I. 2009. Concentrations of ionized and total magnesium and calcium in healthy horses: effects of age, pregnancy, lactation, $\mathrm{pH}$ and sample type. Vet. J. 181: 305-311. [Medline] [CrossRef]

9. Berridge, M.J., Lipp, P., and Bootman, M.D. 2000. The versatility and universality of calcium signalling. Nat. Rev. Mol Cell Biol. 1: 11-21. [Medline] [CrossRef]

10. Carvalho, B.M.R., Bassani, R.A., Franchini, K.G., and Bassani, J.W.M. 2006. Enhanced calcium mobilization in rat ventricular myocytes during the onset of pressure overloadinduced hypertrophy. Am. J. Physiol. Heart Circ. Physiol. 291: H1803-H1813. [Medline] [CrossRef]

11. Case, R.M., Eisner, D., Gurney, A., Jones, Q., Muallem, S., and Verkhratsky, A. 2007. Evolution of calcium homeostasis: from birth of the first cell to an omnipresent signaling system. Cell Calcium 42: 345-350. [Medline] [CrossRef]

12. Danneman, P.J. and Mandrell, T.D. 1997. Evaluation of five agents/methods for anesthesia of neonatal rats. Lab. Anim. Sci. 47: 386-395. [Medline]

13. Escobar, A.L., Ribeiro-Costa, R., Villaba-Galea, C., Zoghbi, M.H., Pérez, C.G., and Mejía-Alvarez, R. 2004. Developmental changes of intracellular $\mathrm{Ca}^{2+}$ transients in beating rat hearts. Am. J. Physiol. Heart Circ. Physiol. 286: H971H978. [Medline] [CrossRef]

14. Fabiato, A. 1982. Calcium release in skinned cardiac cells: variations with species, tissues, and development. Fed. Proc. 41: 2238-2244. [Medline]

15. Ferraz, S.A., Bassani, J.W.M., and Bassani, R.A. 2001. Restdependence of twitch amplitude and sarcoplasmic reticulum calcium content in the developing rat myocardium. J. Mol. Cell. Cardiol. 33: 711-722. [Medline] [CrossRef]

16. Fukuda, S., Tsuchikura, S., and Iida, H. 2004. Age-related changes in blood pressure, hematological values, concentrations of serum biochemical constituents and weights of organs in the SHR/Izm, SHRSP/Izm and WKY/Izm. Exp. Anim. 53: 67-72. [Medline] [CrossRef]

17. Levy, J.K., Crawford, P.C., and Werner, L.L. 2006. Effect of age on reference intervals of serum biochemical values in kittens. J. Am. Vet. Med. Assoc. 228: 1033-1037. [Medline] [CrossRef]

18. Loughead, J.L., Mimouni, F., and Tsang, R.C. 1988. Serum ionized calcium concentrations in normal neonates. Am. J. Dis. Child. 142: 516-518. [Medline]

19. Maier, L.S. 2009. Role of CaMKII for signaling and regulation in the heart. Front. Biosci. 14: 486-496. [Medline] [CrossRef]

20. Milhaud, G., Perault-Staub, A., and Staub, J. 1972. Diurnal variation of plasma calcium and calcitonin function in the rat. J. Physiol. 222: 559-567. [Medline]

21. Nelson, N., Finnström, O., and Larsson, L. 1987. Neonatal reference values for ionized calcium, phosphate and magnesium: selection of reference population by optimality criteria. Scand. J. Clin. Lab. Invest. 47: 111-117. [Medline] [CrossRef] 
22. Piacentino III, V., Weber, C.R., Chen, X., Weisser-Thomas, J., Margulies, K.B., Bers, D.M., and Houser, S.R. 2003. Cellular basis for abnormal calcium transients in failing human ventricular myocytes. Circ. Res. 92: 651-658. [Medline] [CrossRef]

23. Picht, E., DeSantiago, J., Huke, S., Kaetzel, M.A., Dedman, J.R., and Bers, D.M. 2007. CaMKII inhibition targeted to the sarcoplasmic reticulum inhibits frequency-dependent acceleration of relaxation and $\mathrm{Ca}^{2+}$ current facilitation. J. Mol. Cell. Cardiol. 42: 196-205. [Medline] [CrossRef]

24. Sitsapesan, R. and Williams, A.J. 1990. Mechanisms of caffeine activation of single calcium-release channels of sheep cardiac sarcoplasmic reticulum. J. Physiol. 423: 425-439. [Medline]

25. Snopko, R.M., Ramos-Franco, J., Di Maio, A., Karko, K.L., Manley, C., Piedras-Rentería, E., and Mejía-Alvarez, R. 2008. $\mathrm{Ca}^{2+}$ sparks and cellular distribution of ryanodine receptors in developing cardiomyocytes from rat. J. Mol. Cell. Cardiol. 44: 1032-1044. [Medline] [CrossRef]

26. Tordoff, M.G., Hughes, R.L., and Pilchack, D.M. 1998. Calcium intake by rats: influence of parathyroid hormone, calcitonin, and 1,25-dihydroxyvitamin D. Am. J. Physiol. 274: R214-R231. [Medline]

27. Vetter, R., Studer, R., Reinecke, H., Kólar, F., Oštádalová, I., and Drexler, H. 1995. Reciprocal changes in post-natal expression of the sarcolemmal $\mathrm{Na}^{+}-\mathrm{Ca}^{2+}$ exchanger and
SERCA2 in rat heart. J. Mol. Cell. Cardiol. 27: 1689-1701. [Medline] [CrossRef]

28. Wang, W., Lewin, E., and Olgaard, K. 2002. Role of calcitonin in the rapid minute-to-minute regulation of plasma $\mathrm{Ca}^{2+}$ homeostasis in the rat. Eur. J. Clin. Invest. 32: 674-681. [Medline] [CrossRef]

29. Wiegerinck, R.F., Cojoc, A., Zeidenweber, C., Ding, G., Shen, M., Joyner, R.W., Fernandez, J.D., Kanter, K., Rm Kirshbom, P.M., Kogon, B.E., and Wagner, M.B. 2009. Force frequency relationship of the human ventricle increases during early postnatal development. Pediatr. Res. 65: 414-419. [Medline] [CrossRef]

30. Wolford, S.T., Schroer, R.A., Gohs, F.X., Gallo, P.P., Falk, H.B., and Dente, A.R. 1988. Effect of age on serum chemistry profile, electrophoresis and thyroid hormones in beagle dogs two weeks to one year of age. Vet. Clin. Pathol. 17: 35-42. [Medline] [CrossRef]

31. Xu, A., Hawkins, C., and Naranayan, N. 1997. Ontogeny of sarcoplasmic reticulum protein phosphorylation by $\mathrm{Ca}^{2+}$ calmodulin-dependent protein kinase. J. Mol. Cell. Cardiol. 29: 405-418. [Medline] [CrossRef]

32. Ziman, A.P., Gómez-Viquez, N.L., Bloch, R.J., and Lederer, W.J. 2010. Excitation-contraction coupling changes during postnatal cardiac development. J. Mol. Cell. Cardiol. 48: 379-386. [Medline] [CrossRef] 